\title{
Impact of tobacco tax reforms on tobacco prices and tobacco use in Australia
}

\author{
M Scollo, S Younie, M Wakefield, J Freeman, F Icasiano
}

Tobacco Control 2003;12(Suppl II):ii59-ii66

See end of article for authors' affiliations

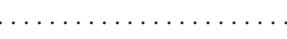

For correspondence:

$S$ Younie, VicHealth Centre

for Tobacco Control, The

Cancer Council Victoria,

Australia;

Sandra.Younie@

cancervic.org.au

\begin{abstract}
Objective: To document the impact of changes to tobacco taxes on the range and price of tobacco sold during the period when the National Tobacco Campaign (NTC) was run.

Data sources: Information about brand availability, pack size, and price was extracted from Australian Retail Tobacconist. A retail observational survey was undertaken to monitor actual retail prices. Data on cigarette prices, brands, packet configurations, and outlets from which they were purchased were obtained from the benchmark and three follow up population telephone surveys conducted to evaluate the NTC.

Method: Data from the three sources were compared to see the extent to which the impact of tax changes had been offset by greater retail discounting and a more concerted effort by consumers to purchase cheaper products.

Results: Smokers were unable to cushion themselves from the sharp price increases that occurred during the third phase of the NTC. Both average recommended retail prices of manufactured cigarettes and average actual cigarette prices paid by smokers increased by $25 \%$ in real prices.

Conclusion: The fall in smoking prevalence over the first two phases of the NTC was substantially greater than would be expected due to tax changes alone. The fall in smoking consumption over the first two phases was slightly less than would be expected and in the third considerably higher than would be expected.
\end{abstract}

A recent review of studies conducted in high, middle, and low income countries found that tax increases resulting in higher tobacco prices were the most effective intervention available to governments to reduce demand for tobacco. ${ }^{1}$ The greatest sensitivity to price increases was found among younger men and women, those from the lower income levels, and those with lower education levels. ${ }^{1}$ Townsend et al in the United Kingdom found prices to be more effective in reducing demand for tobacco than health information to people from lower socioeconomic groups. ${ }^{2}$ Over the period of Australia's National Tobacco Campaign (NTC) (Hill et al, this issue ${ }^{3}$ ), significant changes were introduced to the way in which tobacco was taxed. Efforts to evaluate the NTC would have been incomplete without some indication of the contribution of taxation changes in reducing population smoking prevalence and consumption.

The NTC was a mass media campaign, involving a cooperative partnership between the National and State jurisdictions, that commenced in June 1997. For evaluation purposes, the campaign was separated into three phases: May to November 1997, November 1997 to November 1998, and December 1998 to November 2000. It is both the most intense and longest running anti tobacco campaign run in Australia, with large amounts of resources utilised particularly in the first six months of the campaign (a more detailed explanation and examination of the NTC is provided in the article by Hill et $\mathrm{al}^{3}$ ).

By way of setting the context for this study, it is important to understand that in Australia, cigarettes and manufactured tobacco are sold, broadly speaking, in two market sectors. Firstly, they are sold in the convenience sector, which consists of a large number of shops where people purchase for convenience (most of these outlets sell manufactured cigarettes at or close to the recommended retail price). Secondly, large numbers of smokers purchase products-either in packs or cartons-from supermarkets and from specialist tobacconists at prices well below the recommended retail prices. ${ }^{4}$

The majority of Australian tobacco smokers use manufactured cigarettes and, prior to 1999, cigarette brands could be split into three reasonably clear segments: premium, value and budget. ${ }^{5}$ Value brands were somewhat lighter in weight, so that more cigarettes could be squeezed into a pack. Because tobacco excise was based on the weight of tobacco up to 1999 , each value cigarette attracted less excise, making value packs cheaper (per stick) at the wholesale level and therefore increasingly attractive in the face of increases in State value based wholesale licence fees. In contrast, the budget segment was first introduced in 1990 in packets of 50, by which time state licence fees had increased to $50 \%$ of the value of wholesale sales. Budget brands are those that, when first introduced, contained more than 40 cigarettes.

Over the period of the NTC, the Australian tobacco industry was subject to some major changes in government fiscal policy. These include the end of State franchise fees in August 1997 and the consequent end of the opportunity for cross border and "between state" evasion of cigarette taxes; the shift from a weight to a stick based system of levying excise duty on cigarettes from the 1 November 1999; and the imposition of a Goods and Services Tax (GST) on tobacco products from 1 July 2000.

As well, during this period, in mid-1999 Rothmans and Wills cigarette companies merged (now trading as British American Tobacco Australia (BATA)) and the United Kingdom based Imperial Tobacco entered the Australian market, a condition imposed by the Australian Competition and Consumer Commission in approving the merger.

The combined effect of these factors on the Australian tobacco market was quite dramatic. There was an increase in the range of brands available. Recommended prices increased, particularly in the budget segment of the market, greatly reducing the previously very large differential in the price per stick of light budget and heavier premium cigarettes. There were also reports of greatly increased availability of roughly processed tobacco that did not attract tobacco excise duty and possession of which has recently been declared illegal.

Abbreviations: NTC, National Tobacco Campaign; GST, Goods and Services Tax; BATA, British American Tobacco Australia; RYO, roll your own 
It was predicted that the shift to a per stick system would lead to sharp increases in the price of larger pack formats and, in response, an immediate reduction in consumption among smokers continuing to use larger pack sizes. More importantly, it was predicted that, in the longer term, fewer people would regularly smoke large packs, and that this would also reduce the prevalence of very heavy smoking. Finally, it was hoped that the lower prevalence of heavy smoking would translate, eventually, to higher population quit rates.

This study provides the first information about the impact of tax changes on recommended and actual retail prices and documents changes in smoker consumption patterns over the period of the NTC.

The aims of this study were (a) to document the impact of changes to tobacco taxes announced in the Australian government's 1998 Tax Reform Package ${ }^{6}$ on the range of tobacco products sold in Australia, and on prices at the retail level; (b) to assess changes that remaining smokers may have adopted in an attempt to offset the impact of price increases (in particular, in the types of tobacco products used, the brands preferred, and the outlets from which products are purchased, among both blue and white collar smokers); and (c) to compute a preliminary estimate of how much price pressures could be expected to have contributed to the recent decline in smoking prevalence and the decline in tobacco consumption in Australia over the first three phases of the NTC.

\section{METHODS}

\section{Assessing product availability and retail prices}

To assess changes in the availability and prices of manufactured cigarettes over the period of the NTC, data were compiled and analysed from three sources.

\section{Analysis of trade magazine price lists}

Firstly, information about brand availability and price was extracted from May 1997 and November (1996-2000) editions of the retail trade magazine, Australian Retail Tobacconist. The number of brands available for sale in each pack size and within each of the identified market segments were plotted for each of the phases of the NTC. Average recommended retail price per stick for popular brands within each of several market segments were plotted, highlighting changes in recommended retail prices resulting from the November 1999 excise change, the introduction of the GST in June 2000, and related indexation of tobacco excise duty in August 2000.

\section{Price monitoring survey}

Secondly, a comprehensive survey of six popular cigarette brands (premium brands Winfield (25) and Benson and Hedges (25), value brands Peter Jackson (30), Escort (35) and Longbeach (40), and budget brands Horizon (50) and Holiday (50)) was undertaken across Australia, in order to monitor actual retail prices across a range of locations and outlets. Actual cigarette price data were collected in 55 postcode locations selected throughout Australian capital cities and major regional centres, roughly two for each State health department region covering the city and surrounds. Collectors were asked to find the supermarket and the specialist tobacconist closest to the post office relevant to each area they were assigned. From these outlets they were asked to collect as many as possible of the prices of the cigarette packs and cartons nominated for each State. In addition they were asked to collect pack prices in a further 10 retail outlets, selected using a procedure similar to that described in Houston ${ }^{7}$ and Mullins and Powell. ${ }^{8}$ Collectors were asked to collect as many prices as possible on up to five cigarette brands, based on brand preferences in each State. ${ }^{9}$ Further detail about the survey methodology is available elsewhere. ${ }^{4}$ Data from the survey were plotted for various brands and outlet types, and the average actual retail price per stick calculated for premium, value, and budget brands at discount and convenience outlets across the various phases of the campaign.

\section{Survey of prices paid by smokers}

Thirdly, respondents to the Commonwealth Department of Health and Aged Care's NTC evaluation surveys were asked about prices paid for cigarettes at benchmark and in each of the three follow up surveys in 1997, 1998, 1999, and 2000. From these data, an average price paid per stick was computed both overall and for upper and lower occupational status groups. Respondents were categorised as white collar workers if they were owners or executives, owned a small business, worked in sales, were semi-professionals. Respondents were categorised as blue collar workers if they were skilled, semi-skilled or unskilled workers, if they were farm owners or farm workers.

The population surveys were commissioned by the Australian Commonwealth Department of Health and Aged Care and conducted by Roy Morgan Research. Sampling procedures are described by Wakefield et a $l^{10}$ and Tan et al this issue. ${ }^{11}$

Once the interviewer made contact with a person in the household aged 18 years or older (the informant), that person was asked about their own smoking status (known as the informant sample) and then was asked to describe the number of persons residing at the household, and for each, their age, sex, and whether they were a smoker or recent quitter. Thus, people aged 18 years and over who answered the telephone reported on all of the residents in their household aged 18 years or older, known as the enumeration sample. Smoking prevalence estimates were therefore calculated for both the informant sample and the enumerated sample. Only those aged 18-40 years were eligible to progress as participants to the complete respondent interview. In this paper, the respondent sample includes only those who were smokers and recent quitters. The respondent's telephone interview included questions about their level of tobacco consumption and type of tobacco smoked, cigarette brand, pack size, where they had purchased their latest pack of cigarettes, and how much they paid for it. Thus, consumption and brand choice data in this study are drawn from the respondent component of the NTC surveys.

Finally, data from the three sources were compared to get a sense of the extent to which the impact of tax changes had been offset by greater retail discounting and a more concerted effort by consumers to purchase cheaper products.

\section{Assessing price minimising behaviours among remaining smokers}

To assess the extent to which remaining smokers attempted to offset the effects of price changes, a number of questions were included in each of the NTC surveys concerning product types used, pack size, and brand selected, whether packs were purchased singly or in cartons, and tobacco outlet types patronised. The percentages of smokers using cheaper product types and brands, purchasing in cartons rather than in single packs, and from discounted as opposed to convenience outlets were tabulated for each stage of the campaign, both overall and for white and blue collar groups.

\section{Assessing price related changes in consumption patterns}

To assess the extent to which cigarettes became less affordable over the period of the NTC, the average price paid per cigarette stick was adjusted by the Australian Bureau of Statistics' All capital cities consumer price index $x^{12}$ for the quarter in which the measure was taken. Survey respondents were also asked whether they found cigarettes more affordable and whether they had taken any steps to address this.

Abelson, as part of his contribution to a report to the Commonwealth Health Department on returns on public investment, reviewed Australian and overseas studies of price elasticity of demand for tobacco. He concluded that both the 
Table 1 Number of brand families available in each pack size, November 1994 to 2000

\begin{tabular}{|c|c|c|c|c|c|c|c|c|}
\hline \multirow{2}{*}{$\begin{array}{l}\text { Number of brands } \\
\text { on the market }\end{array}$} & \multirow[b]{2}{*}{ Nov 1994} & \multirow[b]{2}{*}{ Nov 1995} & \multirow[b]{2}{*}{ Nov 1996} & \multirow{2}{*}{$\begin{array}{l}\text { Benchmark } \\
\text { May } 1997\end{array}$} & \multirow{2}{*}{$\begin{array}{l}\text { Follow up } 1 \\
\text { Nov } 1997\end{array}$} & \multirow{2}{*}{$\begin{array}{l}\text { Follow up } 2 \\
\text { Nov } 1998\end{array}$} & \multirow{2}{*}{$\begin{array}{l}\text { Follow up } 3 \\
\text { Nov } 1999\end{array}$} & \multirow{2}{*}{$\begin{array}{l}\text { Follow up } 4 \\
\text { Nov } 2000\end{array}$} \\
\hline & & & & & & & & \\
\hline 20 & 40 & 36 & 36 & 36 & 34 & 35 & 39 & 42 \\
\hline 25 & 18 & 17 & 17 & 17 & 16 & 16 & 16 & 15 \\
\hline 30 & 8 & 9 & 9 & 8 & 8 & 8 & 8 & 9 \\
\hline 35 & 6 & 7 & 7 & 7 & 7 & 7 & 6 & 6 \\
\hline 40 & 3 & 3 & 3 & 3 & 3 & 3 & 4 & 4 \\
\hline 50 & 3 & 3 & 3 & 3 & 3 & 3 & 3 & 3 \\
\hline Total $\mathrm{n}$ brand families & 60 & 59 & 60 & 58 & 54 & 55 & 54 & 54 \\
\hline
\end{tabular}

Table 2 Number of brand variants available in each pack size, 1994 to 2000

\begin{tabular}{|c|c|c|c|c|c|c|c|c|}
\hline \multirow{2}{*}{$\begin{array}{l}\text { Number of brands } \\
\text { on the market }\end{array}$} & \multirow[b]{2}{*}{ Nov 1994} & \multirow[b]{2}{*}{ Nov 1995} & \multirow[b]{2}{*}{ Nov 1996} & \multirow{2}{*}{$\begin{array}{l}\text { Benchmark } \\
\text { May } 1997\end{array}$} & \multirow{2}{*}{$\begin{array}{l}\text { Follow up } 1 \\
\text { Nov } 1997\end{array}$} & \multirow{2}{*}{$\begin{array}{l}\text { Follow up } 2 \\
\text { Nov } 1998\end{array}$} & \multirow{2}{*}{$\begin{array}{l}\text { Follow up } 3 \\
\text { Nov } 1999\end{array}$} & \multirow{2}{*}{$\begin{array}{l}\text { Follow up } 4 \\
\text { Nov } 2000\end{array}$} \\
\hline & & & & & & & & \\
\hline 20 & 75 & 73 & 65 & 63 & 65 & 72 & 99 & 117 \\
\hline 25 & 55 & 51 & 52 & 51 & 51 & 51 & 63 & 63 \\
\hline 30 & 28 & 36 & 36 & 34 & 36 & 39 & 40 & 45 \\
\hline 35 & 28 & 29 & 29 & 29 & 27 & 26 & 23 & 23 \\
\hline 40 & 28 & 21 & 21 & 21 & 21 & 21 & 29 & 29 \\
\hline 50 & 17 & 17 & 17 & 17 & 17 & 17 & 17 & 17 \\
\hline Total & 231 & 227 & 220 & 215 & 215 & 226 & 271 & 294 \\
\hline
\end{tabular}

Source: Australian Retail Tobacconist price lists.

Table 3 Average recommended retail price (cents) per stick for the top 20 brands, average per segment (selected brands only, unweighted), and percentage increase over previous year

\begin{tabular}{|c|c|c|c|c|c|c|c|c|c|}
\hline & & & & Benchmark & Follow up 1 & Follow up 2 & Follow up 3 & Follow up 4 & Increase \\
\hline & Nov 1994 & Nov 1995 & Nov 1996 & May 1997 & Nov 1997 & Nov 1998 & Nov 1999 & Nov 2000 & period \\
\hline Premium & 20.42 & 26.29 & 26.46 & 26.61 & 27.32 & 28.22 & 29.68 & 33.99 & \\
\hline Increase c.f. previous year & & $29 \%$ & $1 \%$ & $1 \%$ & $3 \%$ & $3 \%$ & $5 \%$ & $15 \%$ & $28 \%$ \\
\hline Value & 18.33 & 23.04 & 23.18 & 22.41 & 23.50 & 24.41 & 27.22 & 29.96 & \\
\hline Increase c.f. previous year & & $26 \%$ & $1 \%$ & $-3 \%$ & $5 \%$ & $4 \%$ & $12 \%$ & $10 \%$ & $34 \%$ \\
\hline Budget & 16.27 & 19.68 & 20.73 & 20.95 & 21.37 & 22.21 & 26.23 & 29.73 & \\
\hline Increase c.f. previous year & & $21 \%$ & $5 \%$ & $1 \%$ & $2 \%$ & $4 \%$ & $18 \%$ & $13 \%$ & $42 \%$ \\
\hline All top 20 brands & 18.73 & 22.83 & 23.31 & 23.20 & 23.79 & 24.67 & 27.56 & 31.07 & \\
\hline Increase c.f. previous year & & $22 \%$ & $2 \%$ & $-1 \%$ & $3 \%$ & $4 \%$ & $12 \%$ & $13 \%$ & $34 \%$ \\
\hline $\begin{array}{l}\text { Differential between budget } \\
\text { and premium brands }\end{array}$ & $-20 \%$ & $-25 \%$ & $-22 \%$ & $-21 \%$ & $-22 \%$ & $-21 \%$ & $-12 \%$ & $-13 \%$ & \\
\hline Reduction in differential & & & & & & & & & $-41 \%$ \\
\hline
\end{tabular}

Source: Australian Retail Tobacconist price lists, in Australian dollars. c.f., Compared with.

Australian and international studies give a similar result-an estimated price elasticity of about $-0.4 .^{13}$ This estimate is supported by other studies. ${ }^{14}$ Using this estimate of price elasticity predicted changes in smoking prevalence and consumption were computed for each phase of the NTC. These were compared with actual changes in the percentage of respondents who indicated that they were smokers and the average reported consumption of respondents (remaining smokers) between the benchmark and second and fourth follow up surveys.

\section{Statistical methods and presentation of the NTC survey data}

Relative changes in proportions over time were analysed using logistic regression analysis. Relative changes in means over time were analysed using analysis of variance.

The statistical analysis was conducted on weighted data to compensate for differences between the various State and Territory populations while maintaining the total sample size. Smoking prevalence rates were based on the enumerated samples. Statistical significance was assessed at the 95\% con- fidence interval (95\% CI) and, in the text, differences referred to as significant meet this conventional criterion.

\section{RESULTS}

\section{Product availability and retail prices}

Impact on the number and type of products available Table 1 shows that, after some rationalisation in the mid-1990s, there was little change in the number of manufactured cigarette brand families available in Australia over the period of the NTC. The term "cigarette brand families" encompasses all the variation that occurs within the one brand, for example different numbers of cigarettes, strength of cigarettes, and product presentation (for example soft or hard pack). Although there was little change leading up to and in the early stages of the campaign, most of the popular brand families replicated variants in at least one lower pack size shortly before the shift to the per stick system in November 1999. The number of brand families available as 25s, 30s, 35s, 40s, and 50s pack sizes between May 1997 and November 2000 remained constant. Table 1 shows that the number of brand 
Table 4 Average actual retail price per stick for monitored top selling brands-packs and cartons, all stores, weighted by outlet market share as at 1998

\begin{tabular}{|c|c|c|c|c|c|c|c|c|c|}
\hline & & & & Benchmark & Follow up 1 & Follow up 2 & Follow up 3 & Follow up 4 & \\
\hline & Nov 1994 & Nov 1995 & Nov 1996 & May 1997 & Nov 1997 & Nov 1998 & Nov 1999 & Nov 2000 & NTC period \\
\hline Premium & & & & 23.86 & 24.78 & 25.61 & 26.88 & 30.84 & \\
\hline Inc c.f. prev & & & & & $4 \%$ & $3 \%$ & $5 \%$ & $15 \%$ & $29 \%$ \\
\hline Value & & & & 20.31 & 21.03 & 21.67 & 24.51 & 28.41 & \\
\hline Inc c.f. prev & & & & & $4 \%$ & $3 \%$ & $13 \%$ & $16 \%$ & $40 \%$ \\
\hline Budget & & & & 18.20 & 18.95 & 19.56 & 22.69 & 27.00 & \\
\hline Inc c.f. prev & & & & & $4 \%$ & $3 \%$ & $16 \%$ & $19 \%$ & $48 \%$ \\
\hline
\end{tabular}

Source: Centre for Behavioural Research in Cancer NTC Price Monitoring Surveys.

Inc, Increase; c.f., compared with; prev, previous.

\begin{tabular}{|c|c|c|c|c|c|}
\hline & Benchmark & Follow up 1 & Follow up 2 & Follow up 3 & Follow up 4 \\
\hline Smokers & $\begin{array}{l}\text { May } 1997 \\
\mathrm{n}=881 \\
\text { Cents/stick }\end{array}$ & $\begin{array}{l}\text { Nov } 1997 \\
n=2090 \\
\text { Cents/stick }\end{array}$ & $\begin{array}{l}\text { Nov } 1998 \\
\mathrm{n}=1171 \\
\text { Cents/stick }\end{array}$ & $\begin{array}{l}\text { Nov } 1999 \\
n=1051 \\
\text { Cents/stick }\end{array}$ & $\begin{array}{l}\text { Nov } 2000 \\
n=1053 \\
\text { Cents/stick }\end{array}$ \\
\hline Premium & $25.0(2.4)$ & $25.4(2.6)$ & $26.9(2.5)$ & $27.9(2.6)$ & $31.9 \quad(3.1)$ \\
\hline$\%$ increase benchmark to follow up 4 & & & & & $27.6 \%$ \\
\hline Value & $21.4(2.5)$ & $21.7(2.4)$ & $22.4(2.4)$ & $24.8(2.5)$ & $28.9 \quad(3.0)$ \\
\hline$\%$ increase benchmark to follow up 4 & & & & & $35.0 \%$ \\
\hline Budget & $18.9(1.9)$ & $19.1(1.9)$ & $20.0(1.8)$ & $22.4(2.6)$ & $26.6 \quad(2.2)$ \\
\hline$\%$ in benchmark to follow up 4 & & & & & $40.1 \%$ \\
\hline $\begin{array}{l}\text { Total } \\
\text { a }\end{array}$ & $22.6(3.7)$ & $23.1(3.6)$ & $23.9(3.7)$ & $25.9(3.5)$ & $30.3 \quad(3.7)$ \\
\hline
\end{tabular}

Source: NTC Evaluation respondent surveys.

families available in the 20s pack size, however, increased from 36 in May 1997 to 42 in November 2000.

In each case, the full range of brand variants (cigarettes of the same brand with various machine measured tar levels, for example 4, 6, 8,10, or $12 \mathrm{mg}$ ) were replicated in each of the new pack sizes, and the number of brand variants available in Australia increased from a total of 231 in November 1994 and 215 listed in the May 1997 price list, to 294 in November 2000 -a $37 \%$ increase. As can be seen from table 2, this resulted mainly from an increase in the number of brand variants in the 20 s and 30 s pack sizes.

Following introduction of the per stick system, all three tobacco companies reconfigured a number of the most popular cigarette brands, increasing the amount of tobacco in each cigarette and promoting the reconfigured brands through advertisements in the Australian Retail Tobacconist from August 1999 to April 2000 as "better value for money".

\section{Impact on retail prices of manufactured cigarettes (recommended retail prices)}

The average price per stick for the top 20 brand pack sizes in each segment of the market is shown in table 3. Although increases in State franchise fees and Federal excise duty resulted in significant increases in the recommended prices of premium brands in 1995, the increase in recommended retail prices of budget brands was significantly lower $(21 \%$ for budget brands, compared with $29 \%$ for premium brands), highlighting the potential for lighter weight cigarettes in large packs to undermine tax policy as a means of reducing tobacco consumption.

As intended, the shift to a per stick method of levying excise duty in November 1999, however, resulted in a significantly greater increase in the recommended retail price of budget brands compared to premium brands ( $18 \%$ for budget brands, compared with only $5 \%$ for premium brands). The differential between premium and budget brands (the percentage by which budget brands were cheaper than premium brands) consequently reduced from a high of $25 \%$ in November 1995 to $12 \%$ following the change to the per stick method in November 1999. Further increases in cigarette prices across the board were evident following the introduction of the GST in June 2000. Overall, recommended prices increased by 34\%, which represented a $25 \%$ increase in real terms over the period of the NTC.

Impact on actual retail prices of manufactured cigarettes The average per stick costs for the monitored brands in each market segment are presented in table 4 .

Actual monitored retail prices increased in both the discount and convenience sector for all segments of the market over the period of the campaign but were lower than recommended prices in all phases of the campaign, and substantially lower in discount outlets. Comparing tables 3 and 4, it is evident that actual retail prices appeared to increase more than recommended retail prices for value and budget brands, at least so far as could be ascertained from data on the limited number of brands included in the retail survey.

\section{Impact on prices paid}

Reliable data are not available over the NTC period on the actual and reported prices paid on roll your own (RYO) tobacco, however, extensive data were collected in each NTC survey on what people reported paying for factory made cigarettes. The average price per cigarette in each segment of the market is displayed in table 5 . The same pattern of increase was observed with the discount and convenience sectors, and for pack and carton purchasers. Prices paid for cigarettes increased in all brand segments and increases were roughly equal across occupational status groups.

Comparing tables 3,4, and 5, it is evident that smokers were largely unable to cushion themselves from the sharp price increases that occurred during the third phase of the NTC. Between May 1997 and November 2000, average (unweighted) recommended retail cigarette prices increased by 
Table 6 Summary of changes in prevalence of price minimising behaviours

\begin{tabular}{llllll}
\hline & Benchmark & Follow up 2 & Follow up 4 & \% change & \% change \\
\cline { 2 - 6 } At least weekly smokers & $\begin{array}{l}\text { May 1997 } \\
(\mathrm{n}=921)\end{array}$ & $\begin{array}{l}\text { Nov 1998 } \\
(\mathrm{n}=1239)\end{array}$ & $\begin{array}{l}\text { Nov 2000 } \\
(\mathrm{n}=1155)\end{array}$ & $\begin{array}{l}\text { May } 97 \text { to } \\
\text { Nov 1998 }\end{array}$ & $\begin{array}{l}\text { Nov 98 to Nov } \\
2000\end{array}$ \\
\hline $\begin{array}{l}\text { \% using RYO } \\
\text { \% using budget brands }\end{array}$ & $13 \%$ & $17 \%$ & $22 \%$ & $+31 \%$ & $+29 \%$ \\
$\%$ using 35s, 40s or 50s & $29 \%$ & $14 \%$ & $10 \%$ & $-18 \%$ & $-28 \%$ \\
$\%$ using discount outlets & $48 \%$ & $32 \%$ & $21 \%$ & $+10 \%$ & $-34 \%$ \\
$\%$ using cartons & $14 \%$ & $55 \%$ & $54 \%$ & $+15 \%$ & $-2 \%$ \\
\hline
\end{tabular}

Table 7 Reported daily cigarette consumption among current smokers, by pack size

\begin{tabular}{llllll}
\hline & Benchmark & Follow up 1 & Follow up 2 & Follow up 3 & Follow up 4 \\
\cline { 2 - 6 } At least weekly smokers & $\begin{array}{l}\text { May 97 } \\
(\mathrm{n}=1075)\end{array}$ & $\begin{array}{l}\text { Nov 97 } \\
(\mathbf{n}=2618)\end{array}$ & $\begin{array}{l}\text { Nov 98 } \\
(\mathbf{n}=1496)\end{array}$ & $\begin{array}{l}\text { Nov 99 } \\
(\mathrm{n}=1338)\end{array}$ & $\begin{array}{l}\text { Nov 2000 } \\
(\mathrm{n}=1480)\end{array}$ \\
\hline Mean cigs/day (sd) & $15.4(10.4)$ & $15.7(10.6)$ & $15.3(10.3)$ & $14.8(9.7)$ & $14.1(9.4)$ \\
Pack size 20 & $10.5(7.4)$ & $12.5(11.5)$ & $9.9(7.9)$ & $10.1(7.4)$ & $9.8(7.6)$ \\
Pack size 25 & $13.2(10.0)$ & $13.4(9.0)$ & $12.8(8.3)$ & $12.9(8.1)$ & $13.1(9.8)$ \\
Pack size 30 & $15.0(9.2)$ & $16.4(11.0)$ & $15.5(10.4)$ & $16.2(9.9)$ & $15.1(9.1)$ \\
Pack size 35 & $17.8(10.5)$ & $18.9(9.8)$ & $18.0(10.7)$ & $16.1(10.4)$ & $14.2(5.8)$ \\
Pack size 40 & $18.1(9.8)$ & $18.7(10.0)$ & $20.2(9.6)$ & $17.2(10.0)$ & $17.4(8.7)$ \\
Pack size 50 & $22.3(11.4)$ & $20.9(11.9)$ & $19.2(10.3)$ & $21.6(11.0)$ & $18.4(9.3)$ \\
heavy smokers $(25+)$ & $26 \%$ & $26 \%$ & $24 \%$ & $23 \%$ & $18 \%$ \\
Pack size 20 & $7 \%$ & $10 \%$ & $11 \%$ & $9 \%$ & $5 \%$ \\
Pack size 25 & $23 \%$ & $22 \%$ & $18 \%$ & $17 \%$ & $21 \%$ \\
Pack size 30 & $21 \%$ & $26 \%$ & $24 \%$ & $31 \%$ & $18 \%$ \\
Pack size 35 & $30 \%$ & $30 \%$ & $36 \%$ & $25 \%$ & $5 \%$ \\
Pack size 40 & $29 \%$ & $33 \%$ & $37 \%$ & $30 \%$ & $25 \%$ \\
Pack size 50 & $48 \%$ & $40 \%$ & $30 \%$ & $44 \%$ & $25 \%$ \\
\hline Source: NTC Evaluation respondent surveys. & & & & \\
\hline
\end{tabular}

$34 \%$ and actual prices paid by smokers also increased by $34 \%$. Actual prices paid in each market segment increased in line with recommended retail prices for each brand segment (27.6\% compared with $28 \%$ in the premium sector; $35 \%$ compared with $34 \%$ in the value segment, and $40.1 \%$ compared with $42 \%$ in the budget segment).

Price minimising behaviours among remaining smokers Smokers wishing to minimise the impact of price have a number of options. They can shift, firstly, from cigarettes to RYO tobacco (either wholly or partially); secondly, from premium to either value or budget brands or from value to budget brands; thirdly, from smaller to larger pack sizes (which are better value per stick), or from larger to smaller pack sizes with a lower up front purchase cost; fourthly, from convenience to discount outlets; or fifthly, from pack to carton purchase. Table 6 summarises the prevalence of price minimising behaviour over the course of the NTC.

There was a significant shift to RYO and a shift to discount outlets between phases one and two of the campaign, and a continuing drift towards RYO usage over the third phase. It should be noted, however, that a proportion of the additional smokers using RYO might only have been occasional users, still predominantly smoking factory made cigarettes. There was little change in the percentage of smokers using cartons. As intended by the November 1999 cigarette excise reforms, which differentially increased the price of lighter weight cigarettes, there has been a large shift away from budget brands and large pack sizes.

The extent to which the shifts in prevalence result from differential rates of quitting among budget versus premium smokers or a real shift among remaining smokers to smaller pack sizes is unclear and will be the subject of further research.

Consistent with these observed trends, $52 \%$ of smokers of manufactured cigarettes reported in November 2000 in the
NTC survey that they found cigarettes "more difficult to afford compared with one year ago". Only $9 \%$ found cigarettes more affordable compared with one year ago, with $38 \%$ reporting no change in affordability.

\section{Changes in consumption}

Analysis of data from the NTC respondent surveys indicates a significant decline in reported daily cigarette consumption among smokers over the period of the campaign, both among blue $(-10.2 \%)$ and white collar groups $(-11.48 \%)$.

As anticipated, average daily consumption among remaining smokers using 50s pack sizes appeared to reduce more significantly than consumption among smokers using smaller pack sizes. Table 7 shows reported consumption among daily and weekly smokers using each pack size. The percentage of cigarette smokers classified as "heavy" smokers also declined significantly from 26\% in May 1997 to $18 \%$ in November 2000. The downward linear trend in consumption across the campaign period from a mean of 15.4 cigarettes per day in May 1997 to 14.1 cigarettes per day in November 2000 remained significant $(\mathrm{p}<0.05)$ after taking account of the change in cost per cigarette stick, and any sex, age, education, and occupational status differences.

\section{Contribution of price increases to reduced tobacco use}

To assess the likely contribution to reduced tobacco use of cigarette price increases, it was necessary to first establish how much less affordable cigarettes were in November 2000 compared with November 1998 before the tax reforms, and May 1997 at the commencement of the NTC.

Average per stick prices paid by smokers were adjusted for each phase of the campaign to take account of overall increases in prices of common consumer goods and services (consumer price index) since the previous phase. Average price paid per cigarette rose by $5.8 \%$ between May 1997 and November 1998, a real price increase of $4.3 \%$ after adjusting 
Table 8 Expected changes in smoking prevalence and total consumption due to price effects over the period of the NTC (that is disregarding campaign effects)

\begin{tabular}{|c|c|c|c|c|}
\hline $\begin{array}{l}\text { At least weekly smokers } \\
\text { Estimated price sensitivity of } \\
\text { demand @ }\end{array}$ & $\begin{array}{l}4.3 \% \text { real price increase } \\
\text { May } 97 \text { to Nov } 1998 \\
\text { Smoking prevalence }\end{array}$ & $\begin{array}{l}\text { Consumption among } \\
\text { remaining smokers }\end{array}$ & $\begin{array}{l}17.7 \% \text { real price increase } \\
\text { Nov } 98 \text { to Nov } 2000 \\
\text { Smoking prevalence* }\end{array}$ & $\begin{array}{l}\text { Consumption among } \\
\text { remaining smokers }\end{array}$ \\
\hline $\begin{array}{l}-0.3 \\
-0.4 \\
-0.5 \\
-0.6 \\
-0.7 \\
-0.8\end{array}$ & $\begin{array}{l}-0.65 \% \\
-0.86 \% \\
-1.08 \% \\
-1.29 \% \\
-1.51 \% \\
-2.69 \%\end{array}$ & $\begin{array}{l}-0.65 \% \\
-0.86 \% \\
-1.08 \% \\
-1.29 \% \\
-1.51 \% \\
-2.69 \%\end{array}$ & $\begin{array}{l}-2.65 \% \\
-3.54 \% \\
-4.23 \% \\
-5.31 \% \\
-6.20 \% \\
-7.08 \%\end{array}$ & $\begin{array}{l}-2.65 \% \\
-3.54 \% \\
-4.23 \% \\
-5.31 \% \\
-6.20 \% \\
-7.08 \%\end{array}$ \\
\hline
\end{tabular}

Source: NTC Evaluation respondent surveys; Australian Bureau of Statistics, Consumer Price Index ${ }^{11}$; Centres for Disease Control MMMW bulletins. ${ }^{14}$ ${ }^{*}$ Note, a $4 \%$ relative reduction in smoking prevalence is equivalent to an absolute $1 \%$ decline in prevalence-say from $25 \%$ to $24 \%$.

\begin{tabular}{|c|c|c|c|c|c|}
\hline & Benchmark & Follow up 2 & Follow up 4 & $\%$ change & $\%$ change \\
\hline & May 1997 & Nov 1998 & Nov 2000 & May 97 to Nov 1998 & Nov 98 to Nov 2000 \\
\hline Enumerated & $\begin{array}{l}29.5 \% \\
(n=6536)\end{array}$ & $\begin{array}{l}27.9 \% \\
(n=10306)\end{array}$ & $\begin{array}{l}26.7 \% \\
(n=11923)\end{array}$ & $-5.42 \%$ & $-4.30 \%$ \\
\hline Blue Collar SES & $33.4 \%$ & $32.6 \%$ & $30.6 \%$ & $-2.4 \%$ & $-6.1 \%$ \\
\hline White Collar SES & $25.1 \%$ & $23.0 \%$ & $23.2 \%$ & $-7.6 \%$ & $0.9 \%$ \\
\hline Informant & $\begin{array}{l}30.8 \% \\
(n=2969)\end{array}$ & $\begin{array}{l}28.6 \% \\
(n=4562)\end{array}$ & $\begin{array}{l}27.1 \% \\
(n=5112)\end{array}$ & $-7.1 \%$ & $-5.2 \%$ \\
\hline Blue Collar SES & $34.1 \%$ & $33.1 \%$ & $32.1 \%$ & $-2.9 \%$ & $-3.0 \%$ \\
\hline White Collar SES & $25.6 \%$ & $22.6 \%$ & $22.0 \%$ & $-11.7 \%$ & $-2.7 \%$ \\
\hline
\end{tabular}

Source: NTC Evaluation respondent surveys.

Table 10 Expected compared to actual falls in smoking prevalence and consumption among respondent groups

\begin{tabular}{|c|c|c|c|c|}
\hline \multirow{2}{*}{$\begin{array}{l}\text { Period } \\
\text { Price increase }\end{array}$} & \multicolumn{2}{|c|}{ May 97 to Nov 1998} & \multicolumn{2}{|c|}{ Nov 1998 to Nov 2000} \\
\hline & $4.3 \%$ & & $17.7 \%$ & \\
\hline Expected fall at price demand elasticity & Prevalence & Consumption & Prevalence & Consumption \\
\hline-0.3 & $-0.65 \%$ & $-0.65 \%$ & $-2.65 \%$ & $-2.65 \%$ \\
\hline-0.5 & $-1.08 \%$ & $-1.08 \%$ & $-4.23 \%$ & $-4.23 \%$ \\
\hline-0.7 & $-1.51 \%$ & $-1.51 \%$ & $-6.20 \%$ & $-6.20 \%$ \\
\hline Actual falls & $-5.42 \%$ & $-0.65 \%$ & $-4.30 \%$ & $-7.84 \%$ \\
\hline Percent of reduction plausibly explained by price increases & Prevalence & Consumption & Prevalence & Consumption \\
\hline at -0.5 & $20 \%$ & $166 \%$ & $98 \%$ & $54 \%$ \\
\hline at -0.7 & $28 \%$ & $232 \%$ & $144 \%$ & $79 \%$ \\
\hline
\end{tabular}

Source: NTC Evaluation respondent surveys; Australian Bureau of Statistics, Consumer Price Index ${ }^{11}$; Centres for Disease Control MMMW bulletins. ${ }^{14}$

for a consumer price index increase during this period of $1.4 \%{ }^{12}$ Between November 1998 and November 2000 average price paid per cigarette increased $26.8 \%$, a $17.7 \%$ real price increase after adjusting for a consumer price index increase during this period of $7.7 \% .^{12}$

International research suggests that the price sensitivity of demand for cigarettes in Western countries has traditionally been around $-0.4 .^{15}$ That is, for every $10 \%$ increase in cigarette prices, cigarette consumption can be expected to fall by about $4 \%$. There is also evidence from behavioural studies that price sensitivity of demand may be higher where prices are higher. ${ }^{16}$ Australian cigarette prices are among the highest and least affordable in the world. ${ }^{17-19}$ Price elasticity may also be affected by the context, that is, there may be less capacity for price increases to prompt reductions in consumption in environments where many people have already attempted to quit in response to media campaigns and other tobacco control policies.

In this study, the percentage increases in real prices paid were multiplied by various estimates for demand price sensitivity ranging from -0.3 to -0.8 . Generally, international research has indicated that half or more of the drop in demand tends to be due to reduced smoking prevalence demand, and half or less due to reduced consumption by remaining smokers. ${ }^{20}$ For the purpose of this exercise, an assumption of $50 \%$ prevalence and $50 \%$ consumption impact has been used to generate the expected changes in smoking prevalence and consumption displayed in table 8 .

How do these estimates compare with overall changes in smoking prevalence and consumption over the period of the NTC? Data from these surveys indicate that for the proportion of the population aged 18-40 years, smoking fell by about $9.5 \%$ - a $2.4 \%$ fall in prevalence-over the period of the NTC, with just over $4 \%$ of the reduction occurring in the last two years of the campaign following the tax changes. Table 9 shows that there was a roughly equal decline in prevalence, over the NTC, among blue and white collar groups, with most of the decline among blue collar groups occurring in the third stage of the campaign.

Finally, table 10 indicates that, comparing the expected falls in prevalence and consumption among the respondents, it would seem that the decline in smoking prevalence over the 
first two phases of the NTC was substantially greater than would be expected due to tax changes alone. The fall in smoking consumption among remaining smokers over the first two phases was somewhat less than would be expected given the average price increases.

In the third phase of the campaign, on the other hand, at least two thirds of the decline in smoking prevalence could be due to the impact of tax reforms. The fall in consumption in the third phase was considerably higher than would be expected on the basis of the level of price rises that occurred over the period and internationally accepted estimates of price elasticity of demand.

\section{DISCUSSION}

Australian tobacco tax reforms effectively reduced the affordability of factory made cigarettes, particularly the so called budget brands. Unfortunately the survey did not allow us to assess the extent of the shift to RYO tobacco, however, it is clear that smokers continuing to use manufactured cigarettes have not been able to cushion themselves from the impact of cigarette price increases by shifting to cheaper brands, format, and outlets.

Over the period of the reforms, there was a decline in overall smoking prevalence, a decline in heavy smoking, and a decline in reported consumption among smokers of manufactured cigarettes, particularly those using budget cigarette brands. The decline in cigarette consumption and smoking prevalence occurred across all occupational status groups, with declines in prevalence among blue collar groups occurring more in the latter stages of the campaign following sharp real price increases.

There are a number of possible explanations for these patterns of change. The amount spent on advertising and the population exposure to the advertising during the first phase of the campaign was considerably higher than in latter phases (Hill et al this issue; ' Wakefield et al this issue,; ${ }^{10}$ Tan et al this issue $\left.^{11}\right)$. Although the impact of unpaid media coverage and advertising for nicotine replacement therapies over the past five years also needs to be considered, this analysis suggests that the first and second phases of the NTC exerted a strong downward influence on smoking prevalence.

Although anti-smoking advertising campaigns are very effective in prompting decisions to quit, price rises would appear to be more effective than campaigns in reducing consumption. ${ }^{21} \mathrm{Hu}$ et al in their 1995 study of the relative effects of taxation versus an anti-smoking campaign on cigarette consumption ${ }^{22}$ found that a 25 cent per pack increase in State tax was more effective than the anti-smoking media campaign (expenditure of approximately US\$26 million) in reducing cigarette sales, but they concluded that the strength of the effects observed was influenced by the magnitude of the taxes and the amount of expenditure of the mass media campaign.

The greater decline in smoking prevalence among blue collar workers occurring in the third phase of the campaign, is consistent with the findings of Townsend et $\mathrm{al}^{2}$ and Biener et $_{\mathrm{al}} \mathrm{l}^{23}$ of the lowest socioeconomic groups being most responsive to price increases and to Chaloupka's ${ }^{24}$ findings that people with lower levels of educational attainment are relatively more sensitive to price than those with higher levels. The greater responsiveness in the third phase is also consistent with Bickel's ${ }^{25}$ finding that the responsiveness of demand to price rises increases as real price rises, as the $17.7 \%$ real price increase occurred after a $4.4 \%$ real price increase.

The higher than expected impact of the tax reforms on smoking consumption in the third phase of the NTC could be due to factors such as the predisposing effect of the NTC, and/or some other factor or factors apart from price and government sponsored campaigns.
Biener $e a^{23}$ found that in the face of a US 25 cent per pack excise tax increase in Massachusetts, a 15\% increase in the average price per pack of cigarettes, more adults preferred to switch to a cheaper brand $(28 \%)$ rather than reduce consumption $(17 \%)$. It would seem that recent reforms in the taxation of Australian tobacco products that have effectively removed the option for smokers to switch to cheaper brands, resulted in the larger than expected reduction in consumption. It is unclear whether the decline in consumption was due to greater reductions in smoking prevalence among heavy smokers who tended, prior to reforms, to smoke budget brands, or whether consumption reduced more among previously heavy smokers. This question requires further exploration in subsequent studies.

This study was intended not as a definitive evaluation of the effectiveness of tax reforms in reducing tobacco use, but rather as a preliminary assessment of the impact of reforms based on data collected for a different purpose, that of evaluating the impact of the NTC. A more sophisticated analysis of changes in month to month prevalence or consumption would be necessary to estimate the relative impact of price, government and pharmaceutical advertising, and other possible factors on the overall decline in tobacco use in Australia.

\section{DISCLOSURE}

Melanie Wakefield is a senior editor of Tobacco Control. She was excluded from editor-reviewer correspondence and was not involved in the editorial decision making process for this manuscript.

\section{Authors' affiliations}

M Scollo, S Younie, VicHealth Centre for Tobacco Control

M Wakefield, J Freeman, F Icasiano, Centre for Behavioural Research in Cancer

\section{REFERENCES}

1 Jha $\mathbf{P}$, Chaloupka FJ. The economics of global tobacco control. BM 2000;321:358-61

2 Townsend J, Roderick P, Cooper J. Cigarette smoking by socioeconomic group, sex, and age: effects of price, income, and health publicity. BM 1994;309:923-7.

3 Hill D, Carroll T. Australia's National Tobacco Campaign. Tob Control 2003; 12(Suppl II):ii9-14.

4 Scollo M, Owen T, Boulter J. Price discounting of cigarettes during the National Tobacco Campaign. In: Hassard K, ed. Australia's National Tobacco Campaign: evaluation report volume two. Canberra: Commonwealth Department of Health and Aged Care; 2000: 155-200.

5 Nicholas D, Oldham D. Australian tobacco. Breathe easy. Melbourne: Merrill Lynch, Global Securities Research and Economics Group, 27 April 1998.

6 Costello P. Not a new tax: a new tax system. Canberra: Australian Government Printing Service, 1998.

7 Houston J. Quit evaluation 1986 quit campaign tobacco retailer survey. In: Quit evaluation studies No 2. Melbourne: Victorian Smoking and Health Program, 1988:75-84.

8 Mullins R, Powell M. Results of a survey of signage displayed in tobacco retailers in 1994. In: Quit evaluation studies No.8. Centre for Behavioural Research in Cancer; 1996:153-63.

9 Nielson AC. Market share-top 20 brands nationally and by state. Australian Retail Tobacconist 1996:56(6):3.

10 Wakefield $M$, Freeman J, Boulter J. Changes associated with the National Tobacco Campaign: pre and post campaign surveys compared In: Hassard K, ed. Australia's national tobacco campaign: evaluation report volume one. Canberra: Commonwealth Department of Health and Aged Care, 1999

11 Tan N, Wakefield M, Freeman J. Changes associated with the National Tobacco Campaign: results of the second follow-up survey. In: Australia's National Tobacco Campaign: evaluation report volume two. Canberra: Commonwealth Department of Health and Aged Care, 2000:21-75.

12 ABS. Consumer Price Index, 6401.0. Canberra: Australian Bureau of Statistics, 2001.

13 Abelson P. Economic evaluation of public health programs to reduce tobacco consumption in Australia. In: Abelson P, ed. Second Australian tobacco control conference. Melbourne, 2003.

14 Warner K. The economics of tobacco and health: an overview. In Abedian I, van der Merwe R, Wilkins N, et al, eds. The economics of tobacco control. Cape Town: Applied Fiscal Research Centre, University of Cape Town, 1998:58.

15 Centers for Disease Control and Prevention. Response to increases in cigarette prices by race/ethnicity, income and age groups-US 1976-1993. Morbidity and Mortality Weekly Report 1998;47. 
16 Bickel W, DeGrandepre R, Higgins S, et al. Behavioural economics of drug-self administration. Functional equivalence of response requirement and drug dose. Life Science 1990;47:501-10.

17 Scollo M. The Big Mac index of cigarette affordability. Tob Control 1996;5:69

18 Guindon GE, Tobin S, Yach D. Trends and affordability of cigarette prices: ample room for tax increases and related health gains. Tob Control 2002; $11: 35-43$.

19 Lal A, Scollo M. Big Mac index of cigarette affordability. Tob Control $2002 ; 11 ; 280$.

20 Chaloupka F. How effective are taxes in reducing tobacco consumption. In: The social cost of smoking. Lausanne: Switzerland, 1998.
21 Laugesen M. Tobacco statistics 2000. Auckland: Cancer Society of NZ, 2000.

22 Hu TW, Sung HY, Keeler TE. Reducing cigarette consumption in California: tobacco taxes vs an anti-smoking media campaign. Am J Public Health 1995;85:1218-22

23 Biener L, Aseltrine R, Cohen B, et al. Reactions of adult and teenaged smokers to the Massachusetts tobacco tax. Am J Public Health 1998;88(9): 1389-91

24 Chaloupka F. Rational addictive behaviour and cigarette smoking. Journal of Politcal Economy 1991;99:722-42.

25 Bickel WK, Madden GJ. The behavioural economics of smoking. Cambridge: National Bureau of Economic Research Working Paper 1998; Number 6444

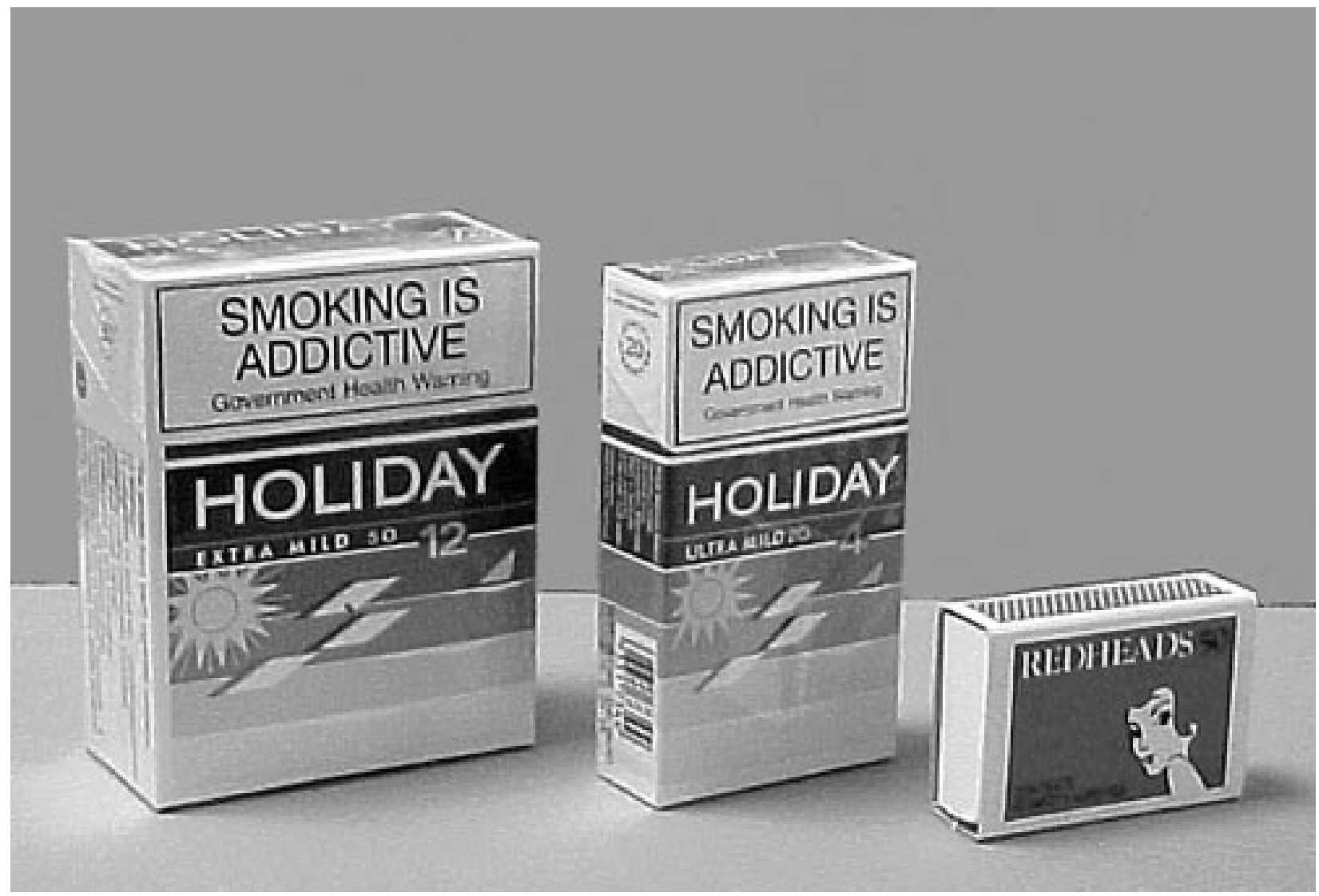

Australia is one of the few countries in the world to have pack sizes up to 50 cigarettes. This photograph compares the pack size of Holiday 50 s with a standard size Holiday pack of 20 cigarettes and a regular pack of matches. 